\title{
Control of root rot (Phytophthora cinnamomi) in avocado (Persea Americana) with bioagents
}

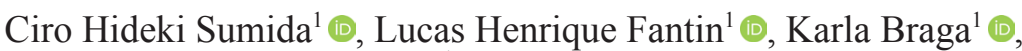 \\ Marcelo Giovanetti Canteri ${ }^{1} \mathbb{0}$, Martin Homechin (in memorian)
}

${ }^{1}$ Universidade Estadual de Londrina, Departamento de Agronomia. Rod. Celso Garcia Cid. (PR 445), Km 380, CP 6001, CEP 86051-990. Londrina, PR, Brasil.

Corresponding author: Karla Braga (karlabraga92@gmail.com)

Data de chegada: 27/02/2018. Aceito para publicação em: 19/12/2019.

$10.1590 / 0100-5405 / 192195$

\section{ABSTRACT}

Sumida, C.H.; Fantin, L.H.; Braga, K.; Canteri, M.G.; Homechin, M. Control of root rot (Phytophthora cinnamomi) in avocado (Persea Americana) with bioagents. Summa Phytopathologica, v.46, n.3, p.205-211, 2020.

Despite the favorable edaphoclimatic conditions for avocado production in Brazil, diseases such as root rot caused by the pathogen Phytophthora cinnamomi compromise the crop. With the aim of managing root rot in avocado, the present study aimed to evaluate chemical and biological control with isolates of Trichoderma spp. and Pseudomonas fluorescens. Thus, three assays were conducted to assess: (i) mycelial inhibition of $P$. cinnamomi by isolates of Trichoderma spp. and $P$. fluorescens from different crop systems; (ii) effect of autoclaved and non-autoclaved metabolites of $P$. fluorescens, and (iii) chemical or biological treatment of avocado seedlings on the control of root rot under field conditions. The isolates of Trichoderma spp. from maize cultivation soil and the commercial products formulated with Trichoderma presented greater antagonism $(\mathrm{p}<0.05)$ to the pathogen $P$. cinnamomi in the in vitro tests. Similarly, non-autoclaved metabolites of $P$. fluorescens presented antagonistic potential to control P. cinnamomi. Under field conditions, the fungicide metalaxyl and the bioagents showed effectiveness in controlling P. cinnamomi, as well as greater root length and mass. Results demonstrated potential for the biological control of avocado root rot with Trichoderma spp. and P. fluorescens.

Keywords: Biological control, Trichoderma spp., Pseudomonas fuorescens.

\section{RESUMO}

Sumida, C.H.; Fantin, L.H.; Braga, K.; Canteri, M.G.; Homechin, M. Controle de podridão radicular (Phytophthora cinnamomi) do abacateiro (Persea americana) com bioagentes. Summa Phytopathologica, v.46, n.3, p.205-211, 2020.

Apesar das condições edafoclimáticas favoráveis para a produção de abacate no Brasil, doenças como a podridão da raiz causada pelo patógeno Phytophthora cinnamomi, comprometem a cultura. Visando o manejo da podridão radicular na cultura do abacateiro, o presente estudo teve como objetivo avaliar o controle químico e biológico com isolados de Trichoderma spp. e Pseudomonas fluorescens. Para isso foram conduzidos três ensaios, em que foram avaliados (i) a inibição micelial de $P$. cinnamomi por isolados de Trichoderma spp. e P. fluorescens provenientes de diferentes cultivos; (ii) efeito de metabólitos autoclavados e não autoclavados de $P$. fluorescens e (iii) o tratamento químico e biológico de mudas de abacateiro para o controle da podridão de raízes em condições de campo. Os isolados de Trichoderma spp. provenientes de solo de cultivo de milho e os produtos comerciais formulados com Trichoderma apresentaram antagonismo superior $(\mathrm{p}<0,05)$ ao patógeno P. cinnamomi nos testes "in vitro". Da mesma forma, metabólitos não autoclavados de $P$. fluorescens apresentaram potencial antagônico para o controle de P. cinnamomi. Em condições de campo, o fungicida metalaxil e os bioagentes apresentaram efetividade no controle de P. cinnamomi e maior comprimento e massa de raízes. Os resultados demonstraram o potencial do controle biológico da podridão radicular do abacateiro com Trichoderma spp. e P. fluorescens.

Palavras-chave: Controle biológico, Trichoderma spp, Pseudomonas fluorescens.

The avocado (Persea americana Mill.) is considered one of the main tropical fruits due to outstanding nutritional quality composed by omega fatty acids, phytosteroids, tocopherols and squalene; it is beneficial to health and can be used in consumption and for the pharmaceutical and cosmetics purposes (11). In the 2017 season, approximately 213,000 tons of fruit were produced in Brazil, with the State of São Paulo (49.8\%), Minas Gerais (25.4\%) and Paraná (10.4\%) accounting for $85.7 \%$ of the country's production (15).

Despite the favorable edaphoclimatic conditions in Brazil, the production is limited due the many factors such as diseases. Root rot in the avocado is caused by the pathogen Phytophthora cinnamomi Rands. The disease is the main phytosanitary constraint in the avocado crop due to the susceptibility of main cultivars and the destructive power of pathogen $(5,23,25)$. Among the management strategies are the use of tolerant rootstocks, acquisition or production of free pathogen seedlings, removal of cultural remains, planting in well-drained soils, balanced fertilization, as well as fungicide application and biological control (1).

Fungi of genus Trichoderma naturally inhabit the soil and can interfere the survival and activity of the plant pathogens, in addition to activating resistance mechanisms of the host plant $(10,4)$. In studies with Trichoderma sp. isolates, the results of Mcleod et al. (18) demonstrated effective control of $P$. cinnamomi. The same was presented in Cavero et al. (8) and Carvalho et al. (6) to the control of Mycosphaerella fijiensis Morelet and Sclerotinia scleotiorum (Lib.) de Bary, respectively. The potential of bacteria such as Pseudomonas sp. as a bioagent of plant pathogen control were observed. Studies showed the potential for control of lettuce root rot caused by Pythium aphanidermatum (Edson) Fitzp. (9) and can promote plant growth as well (28). 
Thus, to evaluate the potential of biological agents as tools in the management of avocado root rot, the present study evaluated the effect of Trichoderma spp. and Pseudomonas fluorescens and their metabolites in the mycelial inhibition of Phytophthora cinnamomi and also the effect of the bioagents and fungicide in the control of the disease in the field.

\section{MATERIAL AND METHODS}

Three assays were developed. In vitro conditions, the first assay evaluated the mycelial inhibition of $P$. cinnamomi using Trichoderma spp. and P. fluorescens isolated from different culture systems (Table 1). The bioassay 2 evaluated the effect of autoclaved and non-autoclaved metabolites of $P$. fluorescens in antagonism to the pathogen $P$. cinnamomi. Bioassays 1 and 2 were carried out in the Phytopathology Laboratory of the State University of Londrina - PR. Assay 3 was conducted in a commercial area in the city of Cerqueira César - SP and evaluated the chemical and biological treatment with Trichoderma spp. and P. fluorescens of avocado seedlings in the control of root rot.

\section{Isolation of Phytophthora cinnamomi}

Phytophthora cinnamomi was isolated according to Zentmyer (32). Soil samples obtained from the rhizosphere of crop areas with plant with symptoms of root rot were added to a three-liter vessel, adding enough water to leave the aqueous layer at the bottom of the vessel. One avocado fruit, used as bait, was submerged in the soil for a period of four days at temperature approximately $28^{\circ} \mathrm{C}$. The fruits were removed from the soil and washed in running water. Approximately $1 \mathrm{~cm}^{2}$ of surface layer was removed and incubated in a moist chamber (gerbox $11 \times 11 \times 4 \mathrm{~cm}$ ) for 3 to 6 days. The colonies were identified based on the observation of reproductive and vegetative structures and then replace in V8-agar medium.

Assay 1- Biological control of Phytophthora cinnamomi with Trichoderma spp. and Pseudomonas fluorescens isolates

The assay was conducted "in vitro" by the culture technique cited by Mello et al. (19) in Petri dishes containing PDA (potato-dextroseagar) medium. The design was completely randomized with five replicates and 16 treatments. The treatments were composed of ten isolates of Trichoderma spp. obtained from different crop systems, four Trichoderma spp. commercial products and two isolates of $P$. fluorescens from the collection of the Phytopathology Laboratory of Londrina State University, Londrina - Pr (Table 1).

Mycelial disks of the $P$. cinnamomi were arranged in plates with PDA culture media. The plates were kept in a climatic chamber at 23 $\pm 3^{\circ} \mathrm{C}$ and photoperiod of 12 hours. The evaluation was based on the mycelial growth, which started four days after the initial of incubation and performed until the moment of control treatment reached the edge of the plates. The diameter of colonies of the pathogens was determined using a millimeter ruler. Mycelial growth inhibition was calculated using the formula:

$\%$ inib $=[($ crcontrol - crtreat $) /$ crcontrol $] \times 100$

where, crcontrol is the mycelial growth of control and crtreat corresponds to the mycelial growth of treatment.
Table 1. Source of isolates of Trichoderma spp., Pseudomonas fluorescens and commercial products based on genera Trichoderma.

\begin{tabular}{|c|c|c|}
\hline Isolate & Crop system & Source \\
\hline Maize DP5* & Maize & Londrina-PR \\
\hline Maize DP6* & Maize & Londrina-PR \\
\hline Maize DA5* & Maize & Londrina-PR \\
\hline Maize DA2* & Maize & Londrina-PR \\
\hline Maize CP4* & Maize & Londrina-PR \\
\hline Avocado & Avocado & Piraju-SP \\
\hline Coconut & Coconut & Mauá da Serra-PR \\
\hline Persimmon & Persimmon & Mauá da Serra-PR \\
\hline Sugarcane & Sugarcane & Londrina-PR \\
\hline Coffee & Coffee & Londrina-PR \\
\hline $\mathrm{C} 1$ & Londrina State University & Londrina-PR \\
\hline $\mathrm{C} 2$ & Londrina State University & Londrina-PR \\
\hline Agrotrich $^{\circledR}$ & Commercial product & - \\
\hline Trich Organic $^{\circledR}$ & Commercial product & - \\
\hline Trichodermil $^{\circledR}$ & Commercial product & - \\
\hline Biotrich $^{\circledR}$ & Commercial product & - \\
\hline
\end{tabular}

Assay 2- Metabolites of Pseudomonas fluorescens in antagonism to Phytophthora cinnamomi

The effect of autoclaved and non-autoclaved metabolites of $P$. fluorescens in antagonism to $P$. cinnamomi was assessed. The design was completely randomized with seven treatments and five replications. The treatments consisted of the metabolites produced by the isolates $\mathrm{C} 1, \mathrm{C} 2$ and $\mathrm{C} 1+\mathrm{C} 2$, submitted or not to the autoclaving process versus the test with only $P$. cinnamomi. The metabolites were obtained from P. fluorescens from the Laboratory of Phytopathology of Londrina State University, Londrina - Pr, multiplied in Potato dextrose medium under agitation for 36 hours, followed by vacuum filtration with filter paper. Subsequently, the medium was poured into the plates, and a disc was deposited at the center of each plate $(5 \mathrm{~mm}$ diameter) from P. cinnamomi colonies from the bait isolation. The mycelial inhibition followed the procedures described in assay 1 .

Assay 3- Chemical and Biological treatment of avocado seedlings inoculated with Phytophthora cinnamomi

The assay was conducted in a commercial area in the city of Cerqueira César - SP. The seedlings of cultivar "Margarida" were obtained by sowing in plastic bags containing a substrate composed of a mixture of $3.0 \mathrm{~kg}$ of single superphosphate, $0.5 \mathrm{~kg}$ of potassium chloride and 100 liters of cattle manure for each cubic meter of soil of ravine. Previously, the substrate was sterilized to ensure not contamination. The solution of inoculum of $P$. cinnamomi was obtained by the crushing of $500 \mathrm{~g}$ of roots of symptomatic plants (Figure 1) per liter of water. The solution was applied in the colon region of seedlings 


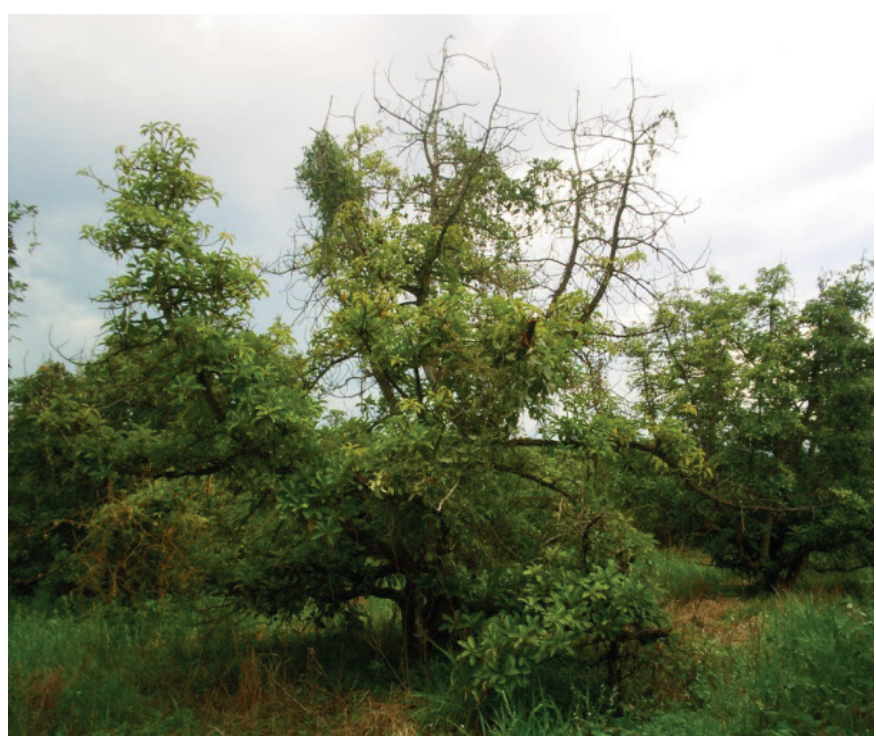

Figure 1. Symptomatic avocado trees with Root Rot - Fazenda Jurumirim- Cerqueira César-SP.

with 30 days $\left(50 \mathrm{~mL} \cdot\right.$ plant $\left.^{-1}\right)$. The experiment was accomplished at a nursery (50\% light). The experimental design was completely randomized with four replicates (seedlings) and 10 treatments.

The biological treatments were composed by the solutions with Trichoderma spp. (persimmon, MaizeCP4, MaizeDP5 and Trichodermil $^{\circledR}$ ), and P. fluorescens ( $\mathrm{C} 1$ and $\left.\mathrm{C} 2\right)$. For the chemical treatment were used fungicide Ridomil ${ }^{\circledR}$ (metalaxil) and the fertilizer Hortifós $^{\circledR}$. The biological treatment consisted of applications in the stem close to root. For this, $5.0 \mathrm{~mL}$ Trichoderma spp. suspension, at the concentration of $1.10^{4}$ spores. $\mathrm{mL}^{-1}$ and $5.0 \mathrm{~mL}$ of $P$. fluorescens suspension were at approximately $120 \mathrm{cfu} \cdot \mathrm{mL}^{-1}$ (colony forming unit) were applied. For the chemical treatments, the solution applied was 0.5 $\mathrm{mL}$ of the Hortifós ${ }^{\circledR}$ fertilizer, diluted in $4.5 \mathrm{~mL}$ of water, and sprayed onto the leaves. The fungicide Ridomil ${ }^{\mathbb{B}}$ was applied to the soil close to stem plant, in the proportion of $0.5 \mathrm{~g}$ of commercial product, diluted in $5 \mathrm{ml}$ of water per seedling. The evaluations were performed at 120 days after application. The evaluated parameters were leaf and root state, plant height and root length, fresh and dry weight of shoot and roots. Leaf and root state were rated according to the characteristics presented by the free control of the pathogen without inoculation (NI) and without treatment (NT).

\section{Statistical analysis}

The data were submitted to analysis of variance (ANOVA) and $\mathrm{F}$ test, with a significance level of 0.05 . The treatments were compared by the Tukey test. Statistical analyzes were performed using the R program (26)

\section{RESULTS AND DISCUSSION}

Biological control of Phytophthora cinnamomi with Trichoderma spp. and Pseudomonas fluorescens isolates

The mycelial inhibition of $P$. cinnamomi due to treatment with Trichoderma spp. (Maize DP5 $=73.3 \%$ and Maize CP4 $=73.3 \%$ ) and commercial products Trichodermil $\AA$, Agrotrich $₫$ and Trich Organic $\AA$ presented inhibition control higher than $70 \%$ and higher than $P$. fluorescens isolates $(\mathrm{C} 1$ and $\mathrm{C} 2)$ as well. The lowest level of control was observed for isolates from soils cultivated with sugarcane, with $24.0 \%$ inhibition (Figure 2).

The inhibition promote by the treatments with P. fluorescens were 40.0 and $44.0 \%$. The results were superior to those presented by the treatments with Trichoderma spp. isolated from coffee, sugarcane

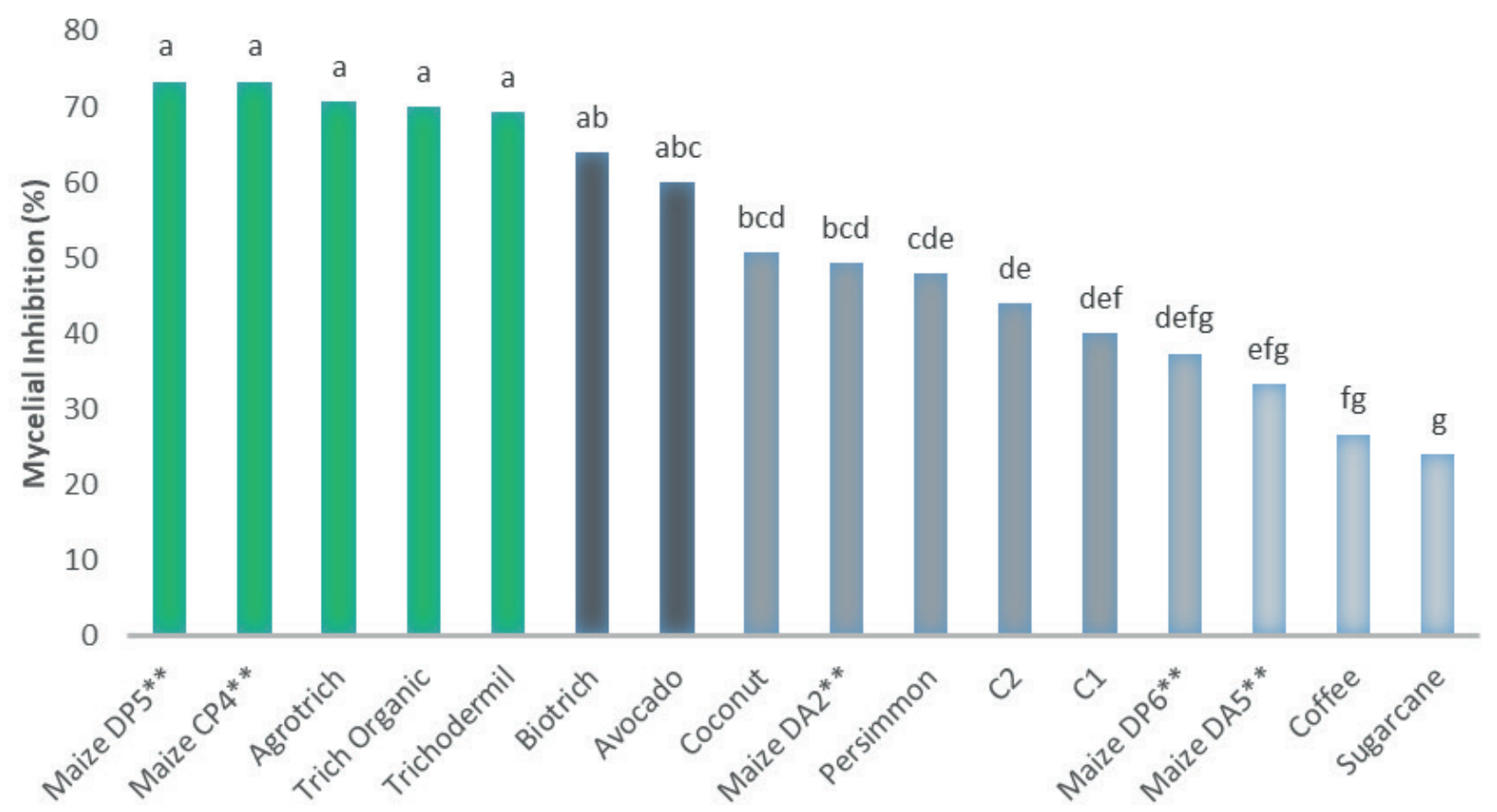

Figure 2. Mycelial Inhibition of Phytophthora cinnamomi by Trichoderma spp. and Pseudomonas fluorescens isolates. ** DA $=$ direct seeding after oats; $\mathrm{DP}=$ no-till after no-till; $\mathrm{CP}=$ conventional sowing after fallow. Means followed by the same letter do not differ by the Tukey test at the $5 \%$ level of significance. 
and no-tillage systems of maize after fallow and oats (maizeDP6 and maizeDA5). In vitro, Méndez-Bravo et al (21) studying the antagonist potential of rhizobacterial isolates from asymptomatic and symptomatic avocado root rot showed inhibition of $P$. cinnamomi micelial growth of $46 \%$ by Bacillus acidiceler. The Pseudomonas baetica isolate presented inhibition less than $10 \%$.

\section{Metabolites of Pseudomonas fluorescens in antagonism to} Phytophthora cinnamomi

The evaluations were performed when the mycelial growth of the control reached the edge of the plaque, approximately 96 hours after inoculation (Figure 3).

The results showed mycelial inhibition for the treatment with autoclaved metabolites T1 (isolate $\mathrm{C} 1$ ), T2 (isolate $\mathrm{C} 2$ ) and T3 (mixture $\mathrm{C} 1+\mathrm{C} 2$ ) less than non-autoclaved T4 (isolate $\mathrm{C} 1$ ), $\mathrm{T} 5$ (isolate $\mathrm{C} 2$ ) and T6 (mixture C1 + C2) (Figure 4). The inhibition of non-autoclaved metabolites was higher than $90 \%$. Autoclaved metabolites produced by isolate $\mathrm{C} 1$ presented less inhibition control (39\%). The mixture of isolates $\mathrm{C} 1$ and $\mathrm{C} 2$ did not presented increases in inhibition control of P. cinnamomi. Working with non-autoclaved metabolites of bacterial isolates obtained from avocado rhizosphere, Ramírez et al. (27) showed inhibitory activity against the evaluated pathogens $P$. cinnamomi, Colletotrichum sp. and Phomopsis sp.

The reduction of effectiveness of autoclaved compounds can be explained by the volatility of compounds produced by the bacteria. Méndez-Bravo et al (21) characterized metabolites produced by bacterial isolates of genera Bacillus, Pseudomonas and Arthrobacter from avocado trees rhizosphere. The authors showed that metabolites are composed by diffusible and volatile parts, and the main volatile compounds produced by the Bacillus were ketones, aldehydes, alkyls, sulfoxides, pyrazines and alcohols. In addition, the bacteria metabolites varying according to genera and species.

Bacterial metabolites have a great potential to control phytopathogens. The characterization of metabolites was studied in many pathosystems, such as the $P$. infestans growth and sporulation was inhibited by compounds Dimethyl disulfide and other sulfurcontaining compounds produced by Pseudomonas (31) as well as the effectiveness of other volatile compounds was presented in the control of Botrytis cinerea, Penicillium digitatum and $P$. italicum (14).
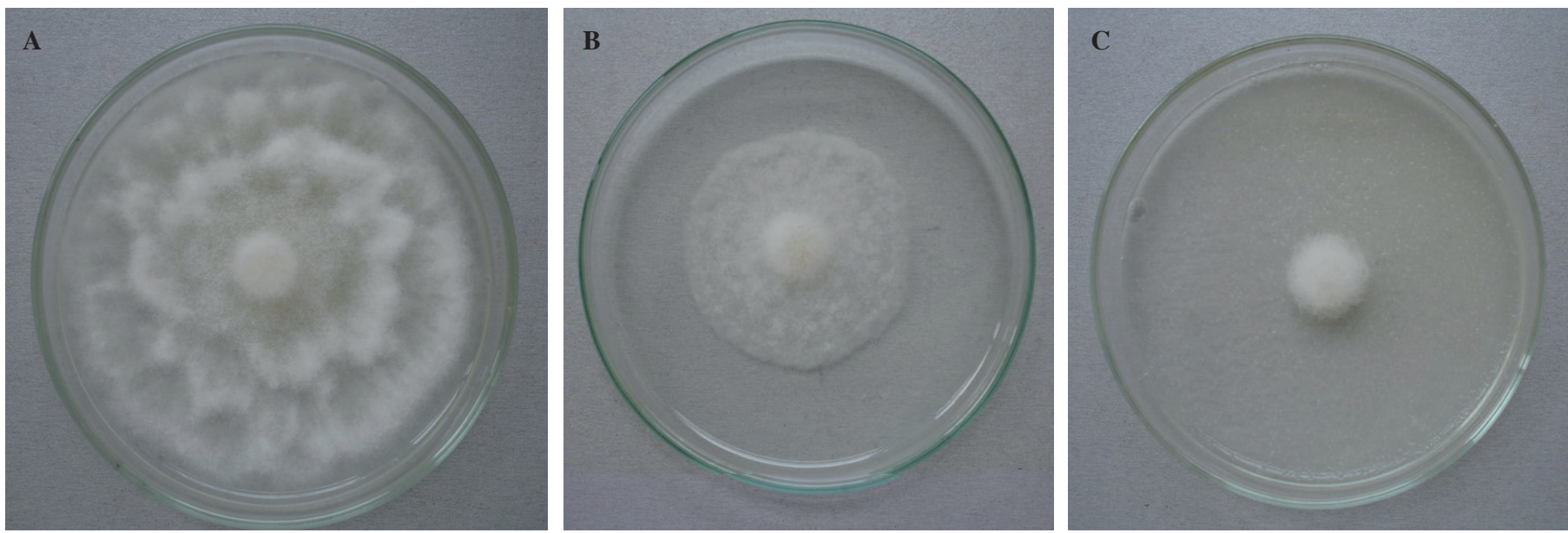

Figure 3. Mycelial Inhibition of Phytophthora cinnamomi submitted to autoclaved and non-autoclaved Pseudomonas fluorescens metabolites 96 hours after inoculation. (A) control treatment without metabolites; (B) treatment "T1" autoclaved metabolite and (C) treatment "T4" nonautoclaved metabolite.

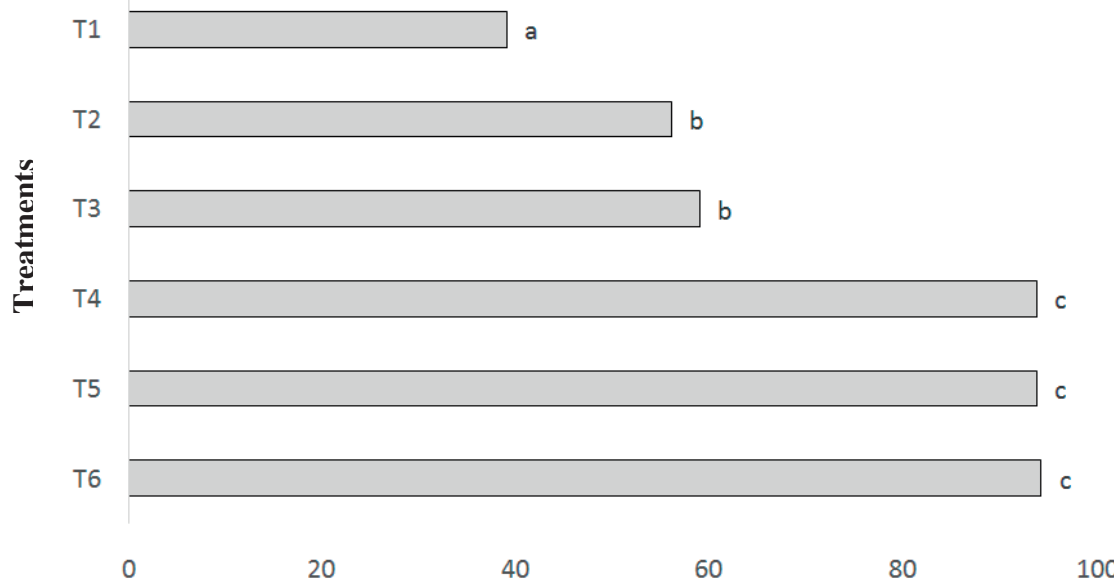

Micelial inhition (\%)

Figure 4. Inhibition of growth of Phytophthora cinnamomi in BDA medium containing Pseudomonas fluorescens Means followed by the same letter do not differ by the Tukey test at the 5\% level of significance. T1, T2 and T3 were autoclaved, T4, T5 and T6 were not autoclaved. 

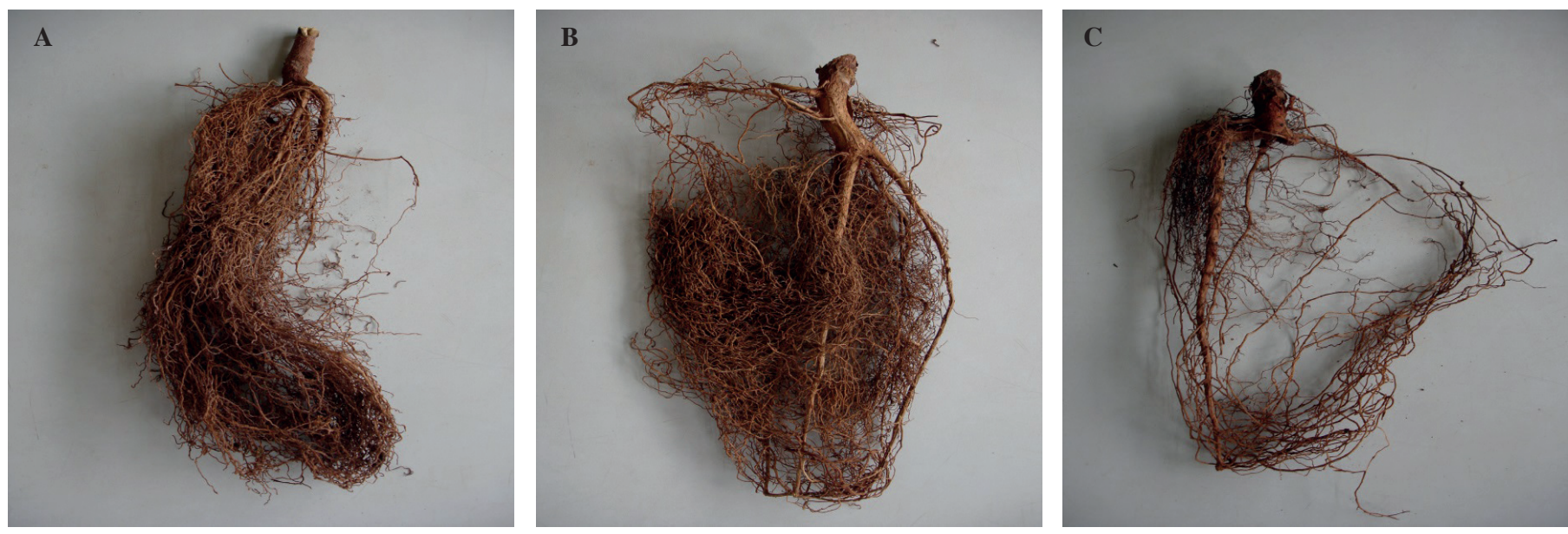

Figure 5. Evaluation of roots of seedlings performed at 120 days after inoculation of Phytophthora cinnamomi. (A) control without inoculation; (B) treatment with application of fungicide Ridomil ${ }^{\circledR}(\mathbf{B})$ and with Trichoderma spp. isolated from soil with persimmon $(\mathbf{C})$.

The results of present study indicated potential of use of metabolites in the control of rot roots in avocado and more studies are necessaries to characterize metabolites produced and the response of them to factors such as temperature, light, etc.

\section{Chemical and Biological treatment of avocado seedlings inoculated with Phytophthora cinnamomi}

There was a reduction in seedling development in treatment with inoculation of P. cinnamomi and without application (NT) (Figure 5).

The treatment with fungicide Ridomil ${ }^{\circledR}$ showed higher development of seedlings for the parameters height, fresh weight, plant dry weight and normal staining; but with regular root length, not differing from other treatments (Table 2).

The results obtained, corroborate those of Leal et al. (16). which observed a reduction in disease severity and in the $P$. cinnamomi population in the soil, as well as an increase in height and dry weight of the seedlings treated with Ridomil ${ }^{\circledR}$. Gonzalez e at (12) showed reduced of growth colony of $P$. cinnamomi of oak higher than $75 \%$ with metalaxyl application. The authors also presented reduced of root lesions in plants with metalaxyl or Potassium phosphite application.

On the other hand, the seedlings treated with Trichoderma from "persimmon" soil (Figure 5C) presented the highest root length, but absence of radicles may compromise the future development of the seedlings due to less capacity of water and nutrient absorption. Different results were present for Stefanello et al. (29), that using Trichoderma harzianum in the control of root rot of cassava, observed increased productivity for the treatments with the use of bioagent. Sumida et al. (30) and Haddad et al. (13) also observed an antagonistic reaction of Trichoderma to isolates of Sclerotinia sclerotiorum, that causes white mold. Méndez-Bravo et al (21) demonstrated that volatile compounds

Table 2. Evaluation of the development of avocado seedlings, inoculated with Phytophthora cinnamomi and treated with bioagents Trichoderma spp. and Pseudomonas fluorescens in commercial area.

\begin{tabular}{|c|c|c|c|c|c|c|c|c|}
\hline \multirow[b]{2}{*}{ Tratamentos } & \multicolumn{4}{|c|}{ Root } & \multicolumn{4}{|c|}{ Aerial } \\
\hline & $\begin{array}{c}\text { lenght } \\
\text { (cm) }\end{array}$ & $\begin{array}{c}\text { WDM } \\
\text { (g) }\end{array}$ & $\begin{array}{l}\text { FW } \\
(\mathrm{g})\end{array}$ & State & $\begin{array}{c}\text { lenght } \\
\text { (cm) }\end{array}$ & $\begin{array}{c}\text { WDM } \\
\text { (g) }\end{array}$ & $\begin{array}{l}\text { FW } \\
\text { (g) }\end{array}$ & State \\
\hline C. WI e NT & $45 \mathrm{a}$ & $22,25 \mathrm{a}$ & $46,5 \mathrm{a}$ & Sympt. & $41 \mathrm{a}$ & $19,5 \mathrm{a}$ & $35,25 \mathrm{a}$ & Sympt. \\
\hline Milho DP5 & $57,75 \mathrm{ab}$ & $24,5 \mathrm{a}$ & $66,5 \mathrm{ab}$ & normal & $48,75 \mathrm{a}$ & $27,5 \mathrm{ab}$ & $52 \mathrm{ab}$ & Sympt. \\
\hline Maize CP4 & 47,75 a & $28,5 \mathrm{a}$ & $60,5 \mathrm{ab}$ & Sympt. & $47,75 \mathrm{ab}$ & $28,5 \mathrm{bc}$ & $60,5 \mathrm{bc}$ & Sympt. \\
\hline Persimmon & $71,33 \mathrm{~b}$ & $29,33 \mathrm{ab}$ & $51,5 \mathrm{a}$ & Sympt. & $44 \mathrm{a}$ & $29 a b$ & $64,7 \mathrm{ab}$ & normal \\
\hline $\mathrm{C} 1$ & $47,5 \mathrm{a}$ & $33,5 \mathrm{ab}$ & $77,5 \mathrm{abc}$ & normal & $61 \mathrm{ab}$ & $51,5 \mathrm{abc}$ & $86,5 \mathrm{abc}$ & normal \\
\hline
\end{tabular}

Means followed by the same letter in the columns do not differ from each other to a $5 \%$ significance level by the Tukey test; C. NI and NT = Control without inoculation and treatment; C. WI and NT = Control with Inoculation and no Treatment; lenght $(\mathrm{cm})=$ length in centimeters; WDM (g) = weight of dry matter in grams; FW $(\mathrm{g})=$ fresh weight in grams, State = situation of root; Sympt = presence of symptoms., normal= No presence of symptoms. 
produced by bacterial isolates from rhizosphere showed biocontrol of soil borne oomycetes such as P. cinnamomi and the antagonism can be related to metabolites produced by bioagents.

Despite of present study showed higher efficiency control of $P$. cinnamomi in seedlings of the chemical control than biological agents, the results demonstrated potential of biological control of avocado root rot. The benefits of bioagents uses are beyond the pathogen inhibition. The use of biological agents or plant extracts may contribute to delay the development of fungicide resistance (7). Marcías-Rodríguez et al. (17) explain that Trichoderma atroviride relationship with tomato plant promoted tomato development and changes in root carbohydrates exudation, consequently provides favorable conditions to the Trichoderma growth and antagonism against $P$. cinnamomi.

In general, the bioagents that survives in plant rhizosphere demonstrated potential to be used in root rot management systems caused by soil pathogens. The results alert the importance of measures to ensure the maintenance of bacterial and fungal community rhizosphere in the equilibrium of crop systems. In this context, more studies of combinations of integrated management such as biofumigation with pellets of plants (22), use of natural essential oils (24), natural plant extracts (2), resistance cultivars $(3,31)$, chemical fungicides and fertilizers such as Potassium phosphite (12) are necessary.

The Trichoderma spp. isolates from maize soil system and commercial biological products (Trichodermil ${ }^{\circledR}$, Agrotrich $^{\circledR}$ and Trich Organic $\left.{ }^{\circledR}\right)$ presented antagonism against the pathogen $P$. cinnamomi in the in vitro tests. In the same way, non-autoclaved metabolites of $P$. fluorescens demonstrate potential antagonistic against $P$. cinnamomi. In field conditions, the fungicide Ridomil ${ }^{\circledR}$ and the bioagents showed effectiveness in controlling P. cinnamomi and greater length and root mass. The results demonstrated potential of biological control of avocado root rot with Trichoderma spp. and P. fluorescens.

\section{ACKNOWLEDGEMENTS}

The authors are grateful for the financial support of the CNPq and Araucária Foundation for Scientific and Technological Development (Paraná, Brazil).

\section{REFERENCES}

1. Amorim, L.; Rezende, J. A. M.; Bergamin Filho, A.; Camargo, L. E. A. Manual de fitopatologia: doenças das plantas cultivadas. 5. ed. Ouro Fino: Agronômica Ceres, 2016. v. 2, 772 p.

2. Arroyo Cordero, F. T.; Rodríguez-Arcos, R.; Jiménez-Araujo, A.; Guillén-Bejarano, R.; Basallote, M. J.; Barrau, C. Inhibitory effect of the glucosinolate-myrosinase system on Phytophthora cinnamomi and Pythium spiculum. Plant Protection Science, Praga, v. 55, p. 93-101. 2019.

3. Belisle, R. J.; McKee, B.; Hao, W.; Crowley, M.; Arpaia, M. L.; Miles, T. D.; Adaskaveg, J. E.; Manosalva, P. Phenotypic Characterization of Genetically Distinct Phytophthora cinnamomi Isolates from Avocado. Phytopathology, St. Paul, v.109, p. 384-394. 2019.

4. Benitez, T.; Rincon, A. M.; Limón, M. C.; Códon, A. C. Biocontrol mechanisms of Trichoderma Strains. International Microbiology, Madrid, v. 7, p. 249-260, 2004.

5. Cantuarias-Avilés, T.; Silva, S. R. The avocado industry in the state of Sao Paulo, Brazil: present and future perspectives. In: Congreso Mundial Del Aguacate, 7., 2011, Cairns: Avocado Source, 2011.

6. Carvalho, D. D. C.; Geraldine, A. M.; Lobo Junior, M.; de Mello, S. C. M. Biological control of white mold by Trichoderma harzianum in common bean under field conditions. Pesquisa Agropecuária Brasileira, Brasília, v. 50, n. 12, p. 1220-1224, 2015.

7. Castillo-Reyes, F.; Hernández-Castillo, F. D.; Clemente-Constantino, J.
A.; Gallegos-morales, G.; Rodríguez-Herrera, R.; Aguilar, C. N. In vitro antifungal activity of polyphenols-rich plant extracts against Phytophthora cinnamomi Rands. African Journal of Agricultural Research, Nigéria, v. 10 n. 50, p. 4554-4560, 2015.

8. Cavero, P. A. S.; Hanada, R. E.; Gasparotto, L.; Coelho Neto, R. A.; Souza, J. T. Controle biológico da Sigatoka-negra da bananeira com Trichoderma. Ciência Rural, Santa Maria, vol.45, n.6, p.951-957, 2015.

9. Cipriano, M. A. P.; Patrício, F. R. A.; Freitas, S. S. Potencial de rizobactérias na promoção de crescimento e controle da podridão radicular em alface hidropônica. Summa Phytopathologica, Botucatu, v.39, n.1, p.51-57, 2013.

10. Cook, R. J.; Baker, K. F. The nature and practice of biological control of plant pathogens. St. Paul: APS, 1983. 539 p.

11. Duarte, P. F.; Chaves, M. A.; Borges, C. D.; Mendonça, C. R. B. Avocado: characteristics, health benefits and uses. Ciência Rural, Santa Maria, v.46, n.4, p.747-754, 2016.

12. González, M.; Caetano, P.; Sánchez, M. E. Testing systemic fungicides for control of Phytophthora oak root disease. Forest Pathology, Hoboken, v. 47, n. 4, 2017.

13. Haddad, P. E.; Leite, L. G.; Lucon, C. M. M.; Harakawa, R. Selection of Trichoderma spp. strains for the control of Sclerotinia sclerotiorum in soybean. Pesquisa Agropecuária Brasileira, Brasília, v. 52, n. 12, p. 1140-1148, 2017.

14. Huang, R.; Li, G. Q.; Zhang, J.; Yang, L.; Che, H. J.; Jiang, D. H.; Huang, H. C. Control of postharvest Botrytis fruit rot of strawberry by volatile organic compounds of Candida intermedia. Phytopathology. St. Paul, v.101, n.7, p. 859-69. 2011

15. Instituto Brasileiro de Geografia e Estatística. Produção Agrícola - Lavoura Permanente. 2018. Disponível em: https://cidades.ibge.gov.br/brasil/pesquisa/15/0. Acesso em: 07 fev. 2018.

16. Leal, J. M.; Castaño, J.; Bolaños, M. M. Manejo de la pudrición radical (Phytophthora cinnamomi RANDS) del aguacate (Persea americana LINNEO). Revista U.D.C.A Actualidad \& Divulgación Científica, Bogotá, v.17, n.1, p.105-114, 2014

17. Macías-Rodríguez, L.; Guzmán-Gómez, A.; García-Juárez, P.; Contreras-Cornejo, H. A. Trichoderma atroviride promotes tomato development and alters the root exudation of carbohydrates, which stimulates fungal growth and the biocontrol of the phytopathogen Phytophthora cinnamomi in a tripartite interaction system. FEMS Microbiology Ecology, Oxford, v.94, n.9, 2018.

18. Mcleod, A.; Labuschagne, N.; Kotzé; Johannes, M. Evaluation of Trichoderma for biological control of avocado root rot in bark medium artificially infested with Phytophthora cinnamomi. South African Avocado Growers' Association Yearbook, v. 18, p. 32-37, 1995.

19. Mello, S. C. M.; Ávila, Z. R.; Braúna, L. M.; Pádua, R. R.; Gomes, D. Cepas de Trichoderma para el control biológico de Sclerotium rolfsii Sacc. Fitosanidad, La Habana, v. 11, n. 1, p. 3-9, 2007.

20. Melo, I. S. Potencialidades de utilização de Trichoderma spp. no controle biológico de doenças de plantas. In: Bettiol, W. Controle biológico de doenças de plantas. Campinas: EMBRAPA/CNPDA, 1991. p. 135-156.

21. Méndez-Bravo, A.; Cortazar-Murillo, E. M.; Guevara-Avendaño, E.; Ceballos-Luna, O.; Rodríguez-Haas, B.; Kiel-Martínez, A. L.; Hernández-Cristóbal, O.; Guerrero-Analco, J. A.; Reverchon, F. Plant growth-promoting rhizobacteria associated with avocado display antagonistic activity against Phytophthora cinnamomi through volatile emissions. Plos One, San Francisco, v.13, n.3, p. e0194665. 2018.

22. Morales-Rodríguez,C.; Vettraino, A. M.; Vannini,A. Efficacy of Biofumigation with Brassica carinata Commercial Pellets (BioFence) to Control Vegetative and Reproductive Structures of Phytophthora cinnamomic. Plant Disease, St. Paul, v.100, n.2, p.324-330. 2016.

23. Nakasone. H. Y.; Paull. R. E. Tropical Fruits. In: Crop production science in horticulture. 2. ed. Wallingford: CABI, 1998. p. 95.

24. Ochoa Fuentes, Y.; Hernández Pérez, A.; Delgado Ortiz, J.; Cerna Chavez, E.; Aguirre Uribe, L.; Tapia-Vargas, L. Control orgánico in vitro de Phytophthora cinnamomi con aceites esenciales de orégano y clavo. Revista Mexicana de Ciencias Agrícolas, Texcoco, v. 10, n. 4, p. 961-968. 2019.

25. Pérez - Jiménez R. M. Significant Avocado Diseases Caused by Fungi and Oomycetes. The European Journal of Plant Science and Biotechnology, Tokyo, v. 21, p. 1-24, 2008.

26. R Core Team. A language and environment for statistical computing. Vienna: R Foundation for Statistical Computing, 2017. Available: https:// www.R-project.org/. 
27. Ramírez Restrepo, S; Arias Marin, J. D.; Bedoya Perez, J. C.; Rueda Lorza, E. A.; Yaneth Sánchez, C.; Granada García, S. D. Metabolites produced by antagonistic microbes inhibit the principal avocado pathogens in vitro. Agronomía Colombiana, Bogotá, v. 33 n. 1, p. 58-63, 2015.

28. Robbs, C. E. Bactérias como agentes de controle biológico de fitopatógenos. In: Bettiol, W. Controle biológico de doenças de plantas. Campinas: EMBRAPA/CNPDA, 1991. p. 121-133.

29. Stefanello, L.; Stefanello, V. F. V.; Heling, A. L.; Henkemeier, N. P.; Roncato, S. C.; Kuhn, O. J.; Stangarlin, J. R. Manejo da podridão radicular da mandioca pela combinação de manejo de solo, variedade resistente e controle biológico com Trichoderma harzianum. Raízes e Amidos Tropicais, Botucatu, v. 13, n. 1, p. 31-45, 2017.
30. Sumida, C. H.; Daniel, J. F. S.; Araújo de, A. P. C. S.; Peitl, D. C.; Abreu, L. M.; Dekker, R. F. H.; Canteri, M. G. Trichoderma asperelloides antagonism to nine Sclerotinia sclerotiorum strains and biological control of white mold disease in soybean plants. Biocontrol Science and Technology, London, v. 28, n. 2, p. 142-156, 2018.

31. De Vrieze, M.; Pandey, P.; Bucheli, T. D.; Varadarajan, A. R.; Ahrens, C. H.; Weisskopf, L.; Bailly, A. Volatile Organic Compounds from Native Potato-associated Pseudomonas as Potential Anti-oomycete Agents. Frontiers in Microbiology, Rockville, v.6, p.1295. 2015.

32. Zentmyer, G. A. Phytophthora cinnamomi and the diseases it causes Monograph $\mathrm{n}^{\circ}$ 10. St. Paul: The American Phytopathological Society, 1980. $96 \mathrm{p}$. 